University of Arkansas, Fayetteville

ScholarWorks@UARK

Education Reform Faculty and Graduate

Students Publications

Education Reform

$4-2-2018$

\title{
Start to Finish: Examining the Impact of the El Dorado Promise on Postsecondary Outcomes
}

\author{
Elsie Swanson \\ University of Arkansas, Fayetteville \\ Gary Ritter \\ University of Arkansas, Fayetteville
}

Follow this and additional works at: https://scholarworks.uark.edu/edrepub

Part of the Educational Assessment, Evaluation, and Research Commons, Educational Leadership Commons, and the Other Educational Administration and Supervision Commons

\section{Citation}

Swanson, E., \& Ritter, G. (2018). Start to Finish: Examining the Impact of the El Dorado Promise on Postsecondary Outcomes. Education Reform Faculty and Graduate Students Publications. Retrieved from https://scholarworks.uark.edu/edrepub/61

This Article is brought to you for free and open access by the Education Reform at ScholarWorks@UARK. It has been accepted for inclusion in Education Reform Faculty and Graduate Students Publications by an authorized administrator of ScholarWorks@UARK. For more information, please contact scholar@uark.edu. 


\title{
畺 UNRKERSITY OF \\ College of Education \& Health Professions \\ Education Reform
}

\section{WORKING PAPER SERIES}

\author{
Start to Finish: \\ Examining the Impact of the El Dorado Promise on Postsecondary Outcomes
}

Elise Swanson and Gary Ritter

Last Revised March 30, 2018

EDRE Working Paper 2018-02

The University of Arkansas, Department of Education Reform (EDRE) working paper series is intended to widely disseminate and make easily accessible the results of EDRE faculty and students' latest findings. The Working Papers in this series have not undergone peer review or been edited by the University of Arkansas. The working papers are widely available, to encourage discussion and input from the research community before publication in a formal, peer reviewed journal. Unless otherwise indicated, working papers can be cited without permission of the author so long as the source is clearly referred to as an EDRE working paper. 
Abstract. The El Dorado Promise is a universal "first dollar" Promise program that guarantees a full tuition scholarship to all students who attend the El Dorado School District from grades K12 , and a partial scholarship for those who enroll in for at least $9^{\text {th }}-12^{\text {th }}$ grade. While prior research on Promise Programs has found that Promise scholarships increase postsecondary matriculation (Daugherty and Gonzalez, 2016; Carruthers and Fox, 2016; Bartik, Hershbein, and Lachowska, 2017), few studies have examined the impact of a Promise scholarship on college completion (Bartik, Hershbein, and Lachowska, 2017) or the differential impact of a Promise scholarship on college completion by student characteristics (Bartik, Hershbein, and Lachowska, 2017; Gonzalez et al. 2011). We use a difference-in-differences strategy to examine the impact of the El Dorado Promise on college enrollment, AA completion, and BA completion on average and by student subgroup (students of color, white students, students with above-average GPAs, and students with below-average GPAs). We find that overall the Promise was associated with an 11.4 percentage point increase in postsecondary enrollment, no change in AA completion, and a 10.7 percentage point increase in BA completion. Students of color and students with belowaverage GPAs saw the biggest gains in college enrollment, while students of color and students with above-average GPAs saw the biggest gains in BA completion. These results indicate that Promise programs operating in rural areas can have a positive and significant impact on postsecondary outcomes for students, particularly students traditionally underrepresented in postsecondary institutions.

Keywords: Promise Programs, postsecondary outcomes, difference-in-differences 


\section{Introduction}

El Dorado, Arkansas, sits just north of the Louisiana border. Spurred by the oil and lumber industries, its population peaked in 1960, with 25,292 residents; however, it began losing residents in 1980 and by 2005 had fewer than 20,000 residents (Population.us). While public school enrollment in Arkansas as a whole has been increasing since the 1990s, El Dorado schools have been losing students steadily since the 1990-91 school year. In 2006, worried about population loss, low academic achievement, and low rates of college attendance, community leaders and Murphy Oil, Corp. executives decided to establish the El Dorado Promise, modeled after the Kalamazoo Promise in Michigan. El Dorado’s universal college scholarship program was endowed with $\$ 50$ million from Murphy Oil, a Fortune 500 company. Officially announced in 2007, the El Dorado Promise guarantees a scholarship to all graduates of El Dorado School District (EDSD) who attended EDSD schools from kindergarten through twelfth grade, and up to $60 \%$ of the scholarship to students who attended EDSD schools from $9^{\text {th }}-12^{\text {th }}$ grade. While Promise programs have three broad goals-increase preparation for college in K-12 classrooms, increase access to postsecondary opportunities, and revitalize the community - the most visible aspect of the Promise is the guarantee of a generous college scholarship. That is the distinguishing feature of these interventions, and the focus of this paper. Specifically, we address three research questions in this paper:

1. Does being eligible for the El Dorado Promise increase students' likelihood of postsecondary enrollment?

2. Does being eligible for the Promise increase students' likelihood of earning a college degree on time; more specifically, are Promise students more likely to earn Associate's 
degree within 3 years of high school graduation or a Bachelor's degree within 6 years of high school graduation?

3. Are there heterogeneous effects of Promise eligibility by student characteristics; that is, is the program particularly effective for African American students or for students with above average prior academic achievement?

The El Dorado Promise scholarship can be used for tuition and mandatory fees for up to five years at any accredited two or four year college or university in the country. The funds must be used for regular undergraduate coursework, but can be used at both private and public institutions. The maximum amount of the scholarship is equal to the highest annual in-state cost (for tuition and mandatory fees) at an Arkansas public university. In the 2017-18 school year, this was $\$ 9,062$ for a student enrolled in 30 credit hours per year. Scholarship funds may be combined with other forms of financial aid, including need-based and merit-based aid, such as the Pell Grant or Arkansas Academic Challenge Scholarship. Since the scholarship amount is determined by the student's tenure in the EDSD and the cost of their tuition and fees, students who receive multiple forms of aid may be able to cover the total cost of college attendance, including housing, food, and textbooks. However, the amount of the Promise scholarship, in conjunction with other sources of grant aid, cannot exceed the total cost of attendance-in other words, students do not receive the Promise scholarship as a refund.

\section{Overview of Promise Programs}

Promise programs are all place-based scholarships with three broad goals: increase access to postsecondary education by providing partial or complete financial assistance; build a collegegoing culture within the Promise community as parents and students learn more, and earlier, about how to prepare for college; and foster community and economic renewal by inducing 
population stabilization or growth in the district (Miller-Adams 2015). However, Promise programs can differ significantly in their design. Promise programs can generally be defined along three dimensions. First, Promise programs can be first or last dollar. First dollar scholarships, like the El Dorado Promise, are awarded to students before they apply for other forms of financial aid or even complete the Free Application For Student Aid (FAFSA). In contrast, last dollar scholarships, like the Hartford Promise in Connecticut, are applied after students apply for all other potential forms of financial aid and "fill the gap" between students' financial aid award the cost of tuition and fees at their postsecondary institution.

Second, Promise programs can be universal, merit-based, or needs-based. Universal programs, like the El Dorado Promise, award scholarships only on the basis of whether the student has attended the district for the appropriate amount of time. Merit-based programs, like the New Haven Promise in Connecticut, require students to meet certain eligibility thresholds, such as a certain GPA cutoff or even community service hours. Need-based programs, such as the Newark College Promise in New Jersey, are targeted towards students from economically disadvantaged families - for example, in order to be eligible for the Newark College Promise, students must live in Newark Housing Authority (NHA) housing or receive an NHA housing voucher.

Finally, Promise programs can be narrow or wide (LeGower and Walsh 2014). Narrow Promise programs, such as the Milwaukee Area Technical College Promise in Wisconsin, only offer a scholarship to 1-3 postsecondary institutions. Wide Promise programs, such as the El Dorado Promise, can be used at a variety of institutions, but it is important to note there is a great deal of diversity in the restrictiveness even of wide Promise programs. For example, the El Dorado Promise scholarship can be used at any accredited two or four year university, while the 
New Haven Promise can only be used at postsecondary institutions in Connecticut and the Say Yes to Education Promise programs in Guilford County, NC, Buffalo, NY, and Syracuse, NY can in general only be used at public universities, unless a private university has joined the Say Yes National Higher Education compact (see Swanson et al. forthcoming for more detail). As a first dollar, universal, wide program, the El Dorado Promise is generous relative even to many other Promise programs.

The El Dorado Promise is also unique among the existing set of Promise programs in that it is located in a predominantly rural area. While most of the existing research examining the effects of Promise programs focuses on programs established in urban areas, evaluations of the El Dorado program will provide unique insight into how these programs might operate in rural areas. Indeed, while we have research on the impact of Promise scholarships in Kalamazoo, Pittsburgh, New Haven, Syracuse, and Buffalo (e.g. Bartik, Eberts, and Huang 2010; Iriti, Bickel, and Kaufman 2012; Daughtery and Gonzalez 2016; Sohn, Rubenstein, Murchie, and Bifulco 2017), there is less work examining programs in El Dorado, Shelby County, TN, Hammond, IN, or McCracken County, KY. Thus, understanding the impacts of the El Dorado Promise will speak not only to that specific community, but also to other rural communities interested in the potential of a Promise program to achieve goals of academic and economic development in their area. As stated previously, while Promise programs have multiple goals, the focal point of any Promise program is the guaranteed college scholarship. In El Dorado, students are guaranteed the full cost of tuition and fees (up to about $\$ 9 \mathrm{~K}$ ) at the postsecondary institution of their choice. In this paper, we are interested in specifically in the effect of this scholarship. Our central research question is: Did the El Dorado Promise increase rates of college enrollment 
and completion among Promise recipients? We then examine whether the Promise had differential impacts by student race or socioeconomic background.

The rest of the paper proceeds as follows. Section II briefly reviews the literature on Promise programs and financial aid and their impact on postsecondary outcomes. Section III outlines our data. Section IV details our analytic strategy for assessing the causal impact of the Promise on postsecondary outcomes. Section V presents our results, and Section VI concludes.

\section{Prior Literature: Financial Aid, Promise Programs, and Postsecondary Outcomes}

In this section, we give a brief overview of the literature examining the impacts of financial aid generally, and Promise programs specifically, on postsecondary outcomes. We focus on both access to postsecondary opportunities—captured by enrollment—and postsecondary success — captured by degree attainment and earnings. We begin by discussing the literature on financial aid broadly, then narrow our focus specifically to Promise programs.

\section{Impacts of Financial Aid}

Generally speaking, students have access to three types of financial aid they can use to pay the costs associated with postsecondary education: grants or scholarships, which do not need to be repaid; loans, which may be offered at no or below-market interest rates by the federal government directly to students or their parents, or by private financial institutions; and workstudy, where a student is offered a job and their salary is partially paid for by the federal government and partially by the university (or whoever their employer is). The majority of research on the impact of financial aid policies has examined the impact of grants on student outcomes (Dynarski and Scott-Clayton, 2013). However, there are exceptions, with some studies explicitly examining the differences in impacts of loans and grants. DesJardins and McCall (2010) examine the records of 12,648 first-time freshmen entering a large research university in 
the 1984, 1986, and 1991 cohorts to study the impacts of different financial aid packages on student outcomes using a multiple-spells competing-risks event history model. Specifically, they look at the risk of graduating, enrolling, and stopping out as a function of ACT composite score, high school rank percentile, lagged college GPA, gender, age at enrollment, initial home location, number of transfer credits at enrollment, college of enrollment, whether the student is from the town the college is located in, out of state, a neighboring state, another state, or a foreign country. They find that all types of aid reduce risk of stop-out, but that grants have a larger impact than loans or work-study. Using simulations, they also find that replacing all loans with grants would reduce the risk of stopping-out by $4 \%$ and increase the likelihood of graduation by $9 \%$.

Grant aid can be separated into two categories: need-based aid, where students qualify for financial assistance based on their (or their family's) income- the federal Pell Grant program is the most recognizable need-based aid program; and merit-based aid, where students qualify for aid based on their academic achievement or other qualifications - the Gates Millennium Scholars Program is an example of this. From their review of the literature, Dynarksi and Scott-Clayton (2013) conclude that although the majority of the research focuses on grant aid, increased financial aid from any source is generally associated with increased college access and completion; however, impacts tend to decrease as the program application process becomes less transparent.

Both need-based and merit-based aid programs have been shown to have positive impacts on college enrollment. In a longitudinal descriptive analysis, Hicks, West, Amos, and Maheshwari (2014) found that reducing the number of semesters a student could receive a Pell Grant from 18 to 12 terms was significantly and negatively associated with enrollment at 
community colleges in rural West Virginia, with enrollment among female minority students decreasing by 7\%. Zhang, Hu, and Sensenig (2013) examined the impact of Florida's Bright Futures merit-based scholarship using a difference-in-differences analysis, and found that receiving the scholarship increased full-time enrollment at 4-year public institutions by $22.3 \%$ and by $19.1 \%$ at public 2-year institutions. However, the literature is far from a consensus on the impact of either need-based or merit-based aid programs on college enrollment. Castleman and Long (2016), examining the need-based Florida Student Access Grant (FSAG) using a sharp regression discontinuity design, found that grant eligibility (worth $\$ 1,300$ in 2000 dollars) was not significantly related to enrollment when considering public, private, and community colleges together. However, the grant did lead to a 3.2 percentage point increase in the probability of enrollment at a public 4-year university. Linsenmeier, Rosen, and Rouse (2006) used a difference-in-difference analysis to examine a private university's initiative to replace loan aid with grant aid for low-income students. They found that overall the policy did not increase enrollment at the university; however, it did lead to a significant and positive increase in enrollment among historically disadvantaged students of color. DesJardins and McCall (2014) used a fuzzy regression discontinuity to examine the impact of the merit-based Gates Millennium Scholars (GMS) Program, finding that it had no statistically significant impact on students' enrollment in either undergraduate or graduate education.

Researchers have also examined the relationship between merit- and need-based aid and college persistence and degree attainment. Castleman and Long (2016) found that the FSAG led to a 4.3 percentage point increase in semester-to-semester persistence in students' first year, a 4credit increase in credit accumulation in the four years after high school graduation, and a 4.6 percentage point increase in BA attainment within 6 years; however, it had no impact on year-to- 
year persistence or AA completion. In a unique experimental study, Goldrick-Rab, Kelchen, Harris, and Benson (2016) found that the need-based Wisconsin Scholars Grant (WSG) was associated with a 1-3 percentage point increase in semester-to-semester persistence, a $.3-.5$ credit increase in credits attained per semester for the first two years of college enrollment, and a 4.7 percentage point increase in BA completion. Zhang, Hu, and Sensenig (2013) found that the Bright Futures program increased BA attainment by $6.6 \%$ and a $10 \%$ increase in AA attainment. DesJardins and McCall (2014) found that the GMS program led to increased GPA and college persistence (but the results were sensitive to bin width); they found no significant impact of the aid on BA completion. Welch (2014), using a fuzzy regression discontinuity to study the Tennessee HOPE scholarship, found that the merit-based aid program was not associated with the number of semesters a student was enrolled in college, final GPA, or degree completion, although the program did lead to a 3.4 credit increase in credits attempted 2 years after initial college enrollment.

Finally, researchers have also examined whether financial aid has differential impacts based on student characteristics. Castleman and Long (2016) find larger impacts of the FSAG for students who had high senior year GPAs in high school than for students with low senior year GPAs, but the largest effects accrue to students who had relatively high GPAs but whose GPAs were not quite high enough to qualify them for the Bright Futures merit-based program. Goldrick-Rab, Kelchen, Harris, and Benson (2016) find no evidence of heterogeneous effects of the WSG program by gender, race, income, but they do find evidence that the WSG had larger impacts for students with college-educated parents and less academically-prepared students. Zhang, Hu, and Sensenig (2013) find no evidence that the impacts of the Bright Futures program differed by race or gender, but for 4-year degrees and all 2-year institution outcomes the effects 
of the program appear to be larger for students of color than white students. Finally, DesJardins and McCall (2014) find some evidence that the impacts of the GMS program differed by student race, with the largest effects of the program on college enrollment and GPA estimated for black students and variation by race in other outcomes as well.

While the findings on the impacts of financial aid are mixed, it seems that generally there is evidence that financial aid programs can impact college enrollment and degree attainment. However, the studies described so far have focused on general financial aid programs, where the only real intervention is the provision of funds to students. In this paper, we are interested in the impacts of a Promise program, which guarantees a college scholarship to all students who graduate from a particular school district. In contrast to other types of financial aid, a Promise program can be expected to impact student outcomes not just by relaxing credit constraints or allowing them to shift resources from work to school, but by improving the quality of instruction students receive during their K-12 education as teachers and administrators know that all students can afford to go to college and by building a college-going culture within the district and community. These mechanisms are detailed in Figure 1.

Figure 1: Theoretical Framework for Promise Programs

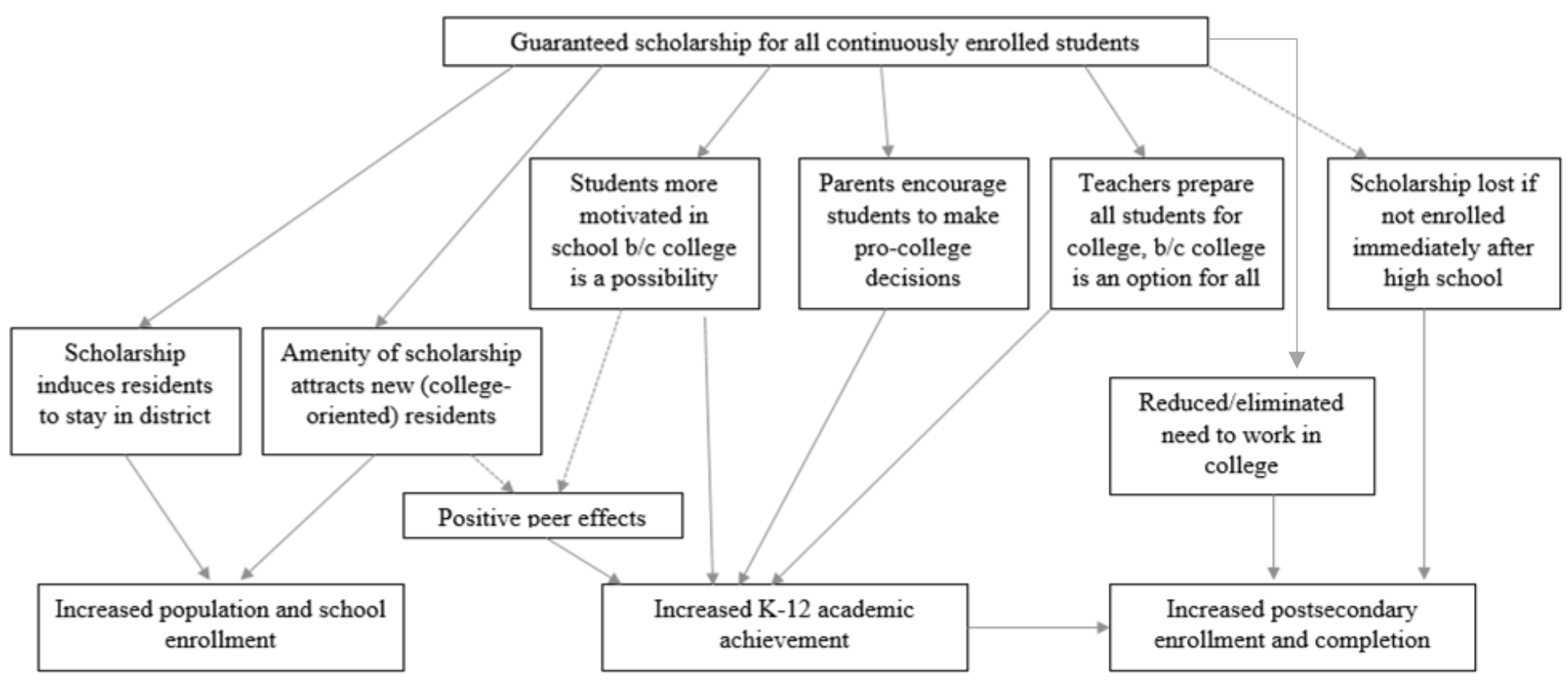


Due to the multiple channels through which a Promise can impact student outcomes, we might expect a Promise program to have greater impacts on college enrollment and completion outcomes than more general forms of financial aid. The next section details the prior research specifically examining the impact of Promise programs on postsecondary outcomes. Postsecondary Impacts of Promise Programs

Carruthers and Fox (2016) examine the impact of the Knox Achieves Promise scholarship on college enrollment and credits earned. The Knox Achieves program was a narrow, universal, last-dollar Promise program available to students who graduated in Knox County, Tennessee from the 2008-09 to the 2011-12 school year, when it expanded to 22 counties in the state and became the Tennessee Achieves program; it expanded again in 2012 and merged with the Tennessee HOPE scholarship to became the statewide Tennessee Promise (Carruthers and Fox, 2016). Carruthers and Fox restrict their analysis to the 2006-07 to 2010-11 school years. Knox Achieves is slightly different from most other Promise programs in that students in the county need to opt into the program, although the program is not competitive. Students who opt into the program are guaranteed a scholarship to a local community college, and have access to a college advisor. They estimate the impact of the program using both a difference-in-differences design and a 1-1 nearest neighbor propensity score matching design. Using propensity score matching, they find that the program led to a 3.4 percentage point increase in high school graduation, a 29.6 percentage point increase in enrollment in community college within 9 months of high school graduation, a 5.2 percentage point decrease in the likelihood of enrolling in a 4-year university, and a 4.9-6.8 increase in credits earned within 2 years of high school graduation. Using their difference-in-differences design, they find a 3-5 
percentage point increase in community college enrollment, but no statistically significant difference in 4-year university enrollment.

Bartik, Hershbein, and Lachowska (2017) examined the impact of the Kalamazoo Promise, a universal, wide, and first-dollar program, on postsecondary enrollment, credits attempted, and degree completion using data from the Kalamazoo school district and National Student Clearinghouse. Using a difference-in-differences design, they found that between 2003 and 2013, the Kalamazoo Promise led to a 8.3 percentage point increase in enrollment within 6 months of high school graduation, a 6.56 credit increase in the number of credits attempted after 4 years, and a 7.4 percentage point increase in 6-year degree completion. Andrews, DesJardins, and Ranchold (2010) also found that the Kalamazoo Promise led to a 6.3 percentage point increase in the share of students who applied to a college or university between 1996 and 2006.

Gonzalez et al. (2014) compared projected and actual trend patterns to assess the impact of the New Haven Promise on college enrollment; they also created conducted a difference-indifferences analysis using a synthetic control district. The New Haven Promise is a merit-based, first-dollar, wide Promise program that also includes turnaround supports for schools. Using district administrative and National Student Clearinghouse data from 2006-07 to 2012-13, they found that the Promise led to a 0.9 to 6.5 percentage point increase in college enrollment using the spline and difference-in-difference analyses, respectively. Similarly, Daugherty and Gonzalez (2016) found that the New Haven Promise led to a 1.3 percentage point increase in postsecondary enrollment using National Student Clearinghouse and New Haven administrative data from 2004 and 2013.

Similar to the New Haven Promise, the Pittsburgh Promise was a merit-based, wide program, but it was a last-dollar instead of first-dollar program. Gonzalez et al. (2011) conducted 
a difference-in-differences analysis to examine the impact of the Promise on both college enrollment and college persistence. They found that for students who graduated between 2006 and 2010, the Promise led to a 3 percentage point increase in college enrollment and a 5 percentage point increase in persistence, but only the impact on persistence was statistically significant. Bozick, Gonzalez, and Engberg (2015) found a positive impact of the Pittsburgh Promise on postsecondary enrollment, but the impact was only significant for enrollment at a four-year institution relative to not enrolling at all.

While the literature on Promise programs has consistently found positive impacts of the programs on college enrollment, the impact of a Promise on degree completion has only been examined for the Kalamazoo Promise (Bartik, Hershbein, and Lachowska, 2017). With the exception of Carruthers and Fox (2016), all of the Promise programs examined for their impact on postsecondary outcomes have been located in urban areas. Further, although the financial aid literature has disaggregated the impact of different types of aid on student subgroups, few studies of Promise programs have (Bartik, Hershbein, and Lachowska, 2017 and Gonzalez et al., 2011 are exceptions). Thus, there is a gap in the literature regarding the impact of Promise programs in rural areas on postsecondary outcomes, the impact of Promise programs on postsecondary degree completion, and the differential impacts of Promise programs on student subgroups. This paper attempts to begin to fill those gaps.

\section{Data}

Data for this paper include administrative data collected by the El Dorado Promise and El Dorado School District (EDSD) and the National Student Clearinghouse (NSC). We have data on 13 graduating classes from EDSD. Cohorts who graduated in 2004, 2005, or 2006 are the prePromise cohorts, while students who graduated between 2007 and 2016 could potentially receive 
the Promise scholarship. In total, we have data on 3,473 students who graduated from the EDSD (the smallest graduating cohort was 215 students in 2004; the largest cohort was 325 students in 2012). All cohorts are included in our enrollment analysis, as we have NSC data through the fall semester of 2017 (the last observed enrollment start date is January 11, 2017). For our analysis of three-year Associate's degree completion, we include students who graduated between 2004 and 2014 (N=2,899). For our analysis of six-year Bachelor's degree completion, we include students who graduated between 2004 and 2011 (N=1,998). For each cohort, we are able to identify students who are (or would have been) eligible for the Promise, based on when they enter the school district. All students who transfer into the district by $9^{\text {th }}$ grade are eligible for a Promise scholarship, with students who attended the district for all grades $\mathrm{K}-12$ receiving the full scholarship amount and with students who enrolled in the district in ninth grade for grades 9-12 receiving $65 \%$ of the maximum scholarship award. In the next section, we describe how we use this simple eligibility criterion to identify the impact of the Promise on postsecondary enrollment and completion. In this section, we present descriptive trends in our data.

We begin by simply describing the students in our data. Table 1 describes the students included in this study by time period.

Table 1: Student Characteristics by Promise Period

\begin{tabular}{rrrrrr}
\hline Demographics & $\begin{array}{r}\text { All El Do } \\
\text { Graduates }\end{array}$ & $\begin{array}{r}\text { All } \\
\text { Eligible }\end{array}$ & $\begin{array}{r}\text { All } \\
\text { Ineligible }\end{array}$ & $\begin{array}{r}\text { Post-Promise } \\
\text { All }\end{array}$ & $\begin{array}{r}\text { Pre-Promise } \\
\text { All }\end{array}$ \\
\hline $\mathrm{N}$ & 3,474 & 2,959 & 474 & 2,777 & 697 \\
& & & & & \\
Female & $52.8 \%$ & $52.8 \%$ & $52.3 \%$ & $52.2 \%$ & $54.8 \%$ \\
Students of Color & $52.5 \%$ & $52.8 \%$ & $50.3 \%$ & $53.1 \%$ & $49.8 \%$ \\
Mean GPA & 2.77 & 2.80 & 2.62 & 2.79 & 2.72 \\
\hline
\end{tabular}

Our total sample includes 3,474 students who graduated from EDSD between 2004 and 2016. Just over half of all students were female; this is consistent for both Promise-eligible and 
Promise-ineligible students. However, a slightly larger share of eligible students were students of color than were ineligible students. Further, the share of students of color increase from the prePromise period to the post-Promise period. Finally, we see that average GPA actually decreased slightly from the pre-Promise to post-Promise period, and that eligible students tended to have higher GPAs than ineligible students. We turn now to a descriptive look at our outcomes of interest: postsecondary enrollment, AA completion, and BA completion.

Figure 2 presents trends in enrollment in any postsecondary institution within 6 months of high school graduation by students' Promise eligibility. The vertical indicates when the Promise was announced, in January 2007.

Figure 2: \% of El Dorado Students Enrolled in ANY Postsecondary Institution within 6 months of High School Graduation, by Promise Eligibility

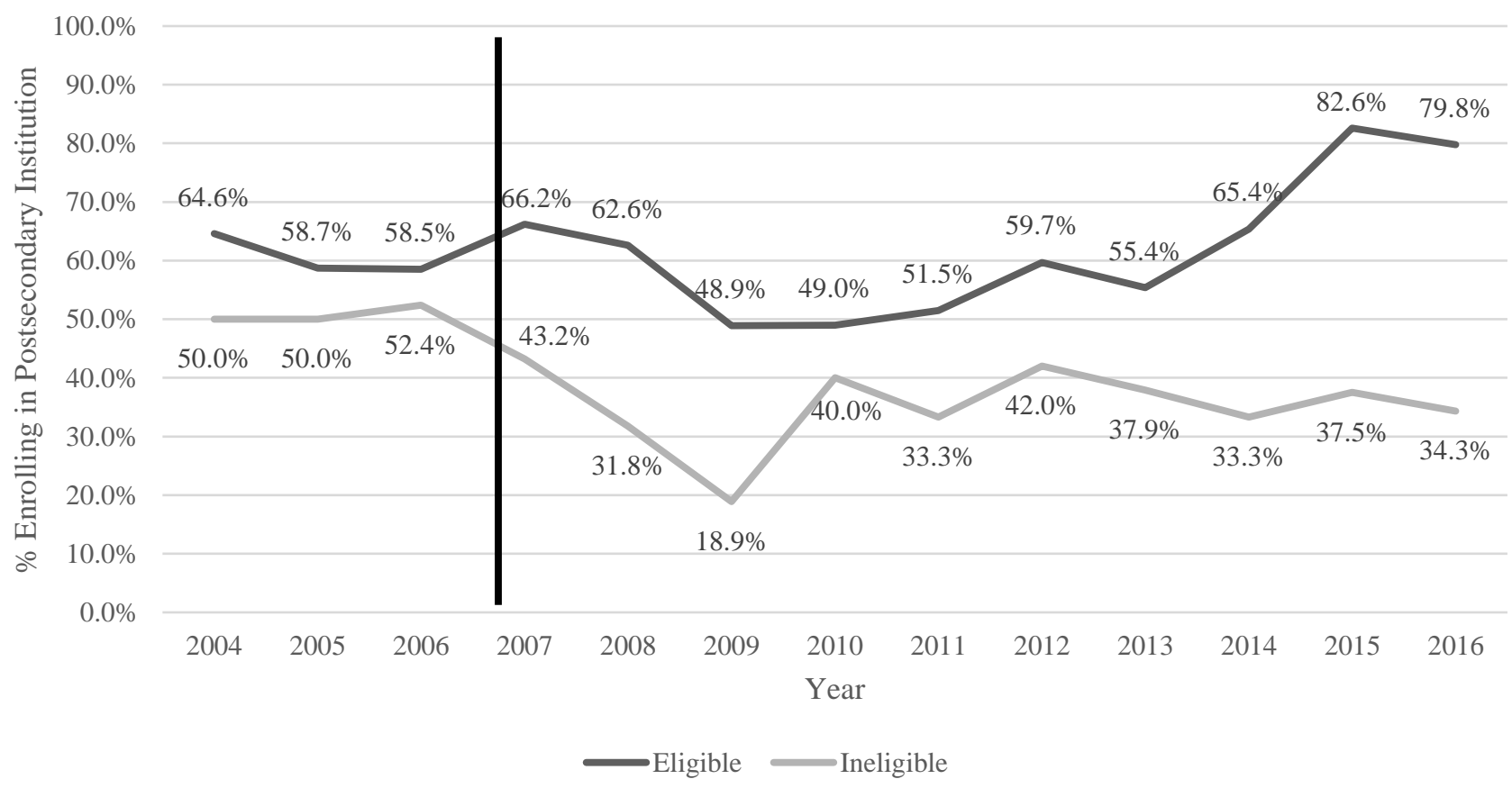

As shown in Figure 2, there were generally similar trends in postsecondary enrollment between Promise eligible and ineligible students prior to the introduction of the Promise, with enrollment rates hovering around $60 \%$ for would-be eligible students and around $50 \%$ for wouldbe ineligible students between 2004 and 2006. For the first cohort of students who could receive 
the Promise, $66.2 \%$ of students enrolled in postsecondary education, while just $43.2 \%$ of ineligible students enrolled in a postsecondary institution. Enrollment rates decreased for both groups between 2007 and 2009, with enrollment rates among eligible students tending upwards following 2009 and more volatile rates among ineligible students. For students in our last observed cohort, $79.8 \%$ of eligible students enrolled in a postsecondary institution, while $34.3 \%$ of ineligible students enrolled in a postsecondary institution within 6 months of graduation.

Figure 3 disaggregates these trends by student race.

Figure 3: \% of El Dorado Students Enrolled in ANY Postsecondary Institution within 6 months of High School Graduation, by Eligibility and Race

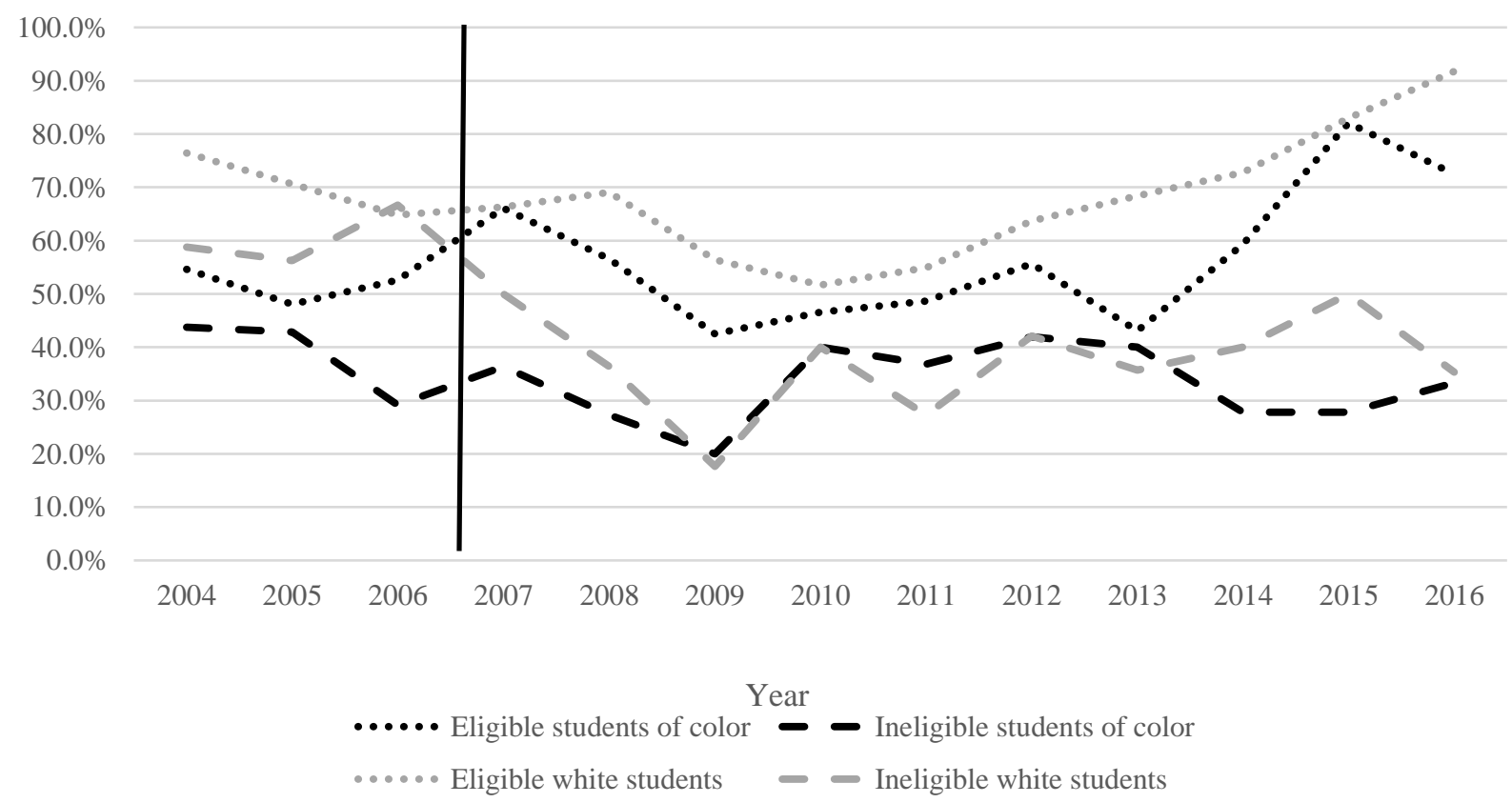

When we split our data by student race and Promise eligibility, we limit the number of observations in each cell, which can lead to volatility in the descriptive trends of enrollment rates over time. However, we can see in Figure 3 that postsecondary enrollment rates for students of color declined between 2004 and 2005, rebounded slightly in 2006 for would-be Promise eligible students, and then followed a similar trend until 2013, when enrollment rates for Promiseeligible students of color increased while enrollment rates for Promise-ineligible students of 
color decreased and flattened out about $30 \%$. For white students, we see in the pre-Promise period that enrollment rates again decreased between 2004 and 2005, then rebounded for the would-be ineligible students in 2006, before increasing in 2007 for the Promise-eligible students and decreasing for the Promise-ineligible students. Following 2007, enrollment rates for eligible white students tended upwards, ending in 2006 at about 73\%, while they remained slightly more volatile for ineligible white students, ending at about $35 \%$ in 2006 . We turn next to trends in enrollment by prior achievement, as measured by high school GPA.

Figure 4: \% of El Dorado Students Enrolled in ANY Postsecondary Institution within 6 months of High School Graduation, by Eligibility and GPA

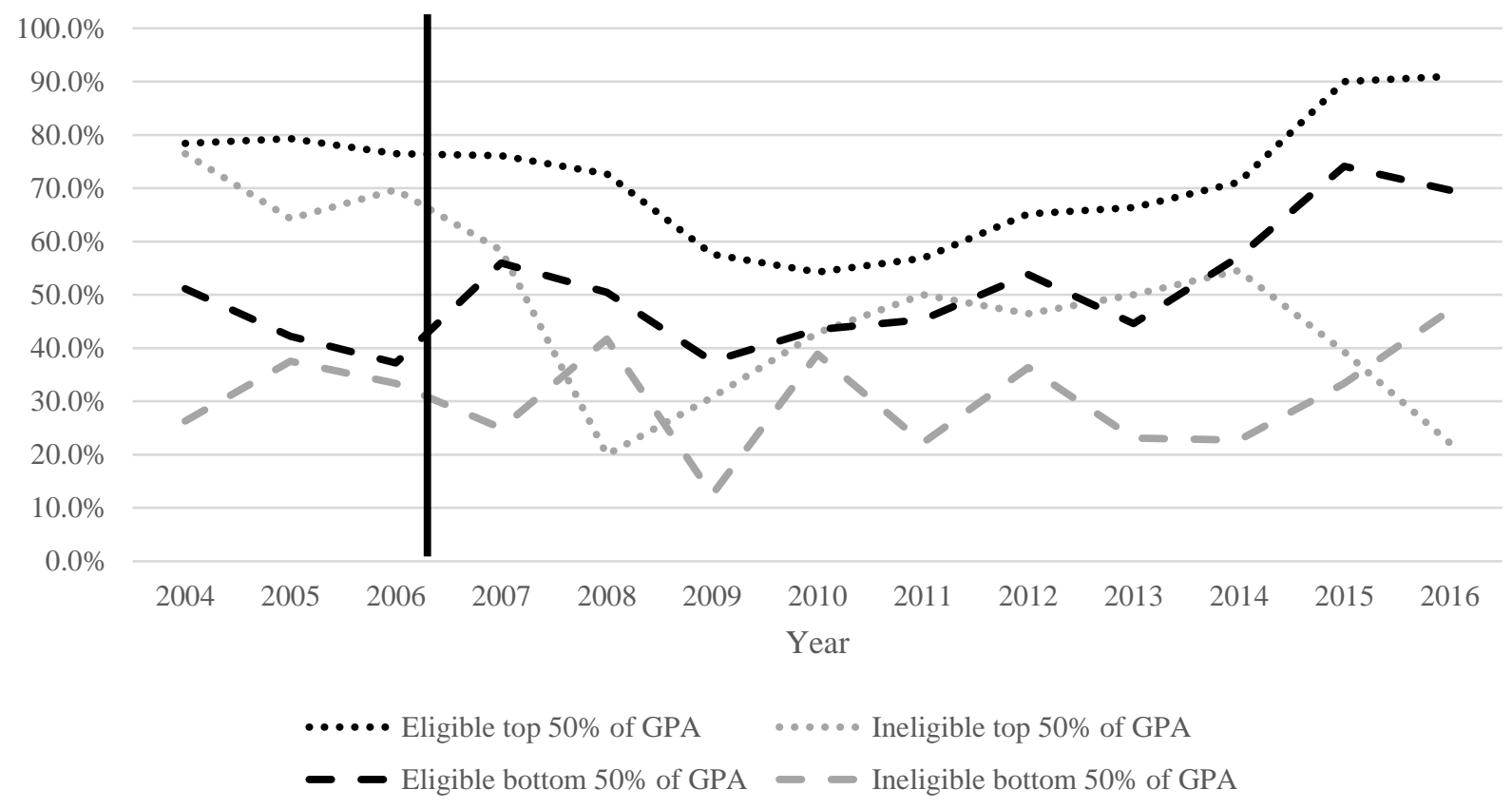

As shown in Figure 4, postsecondary enrollment was relatively flat around $80 \%$ for student with an above-average GPA who would have been eligible for the Promise in 2004-2006, while postsecondary enrollment for would-be eligible students with below-average GPAs was declining over that time. After the announcement of the Promise, enrollment increased, albeit inconsistently, for eligible students with below-average GPAs, but remained relatively flat, although again not consistently, for eligible students with above-average GPAs. For the last 
observed cohort, graduating in 2016, $91 \%$ of eligible students with above-average GPAs enrolled in a postsecondary institution, as did $69.6 \%$ of eligible students with below-average GPAs. The trends for ineligible students are more volatile, in part because of small cell sizes. Ineligible students with above-average GPAs tended to enroll at higher rates than ineligible students with below-average GPAs and, excepting the 2008, 2015, and 2016 cohorts, about $50 \%$ of ineligible students with above-average GPAs tended to enroll in postsecondary education, as did about $30 \%$ of ineligible students with below-average GPAs. Table 2 summarizes the pre- and postPromise average rates of enrollment overall, by race, and by GPA.

Table 2: \% of El Dorado HS Graduates Enrolled at Any Institution within 6 months

\begin{tabular}{cccccc}
\hline & $\begin{array}{c}\text { Pre-Promise } \\
\text { Eligible }\end{array}$ & $\begin{array}{c}\text { Pre-Promise } \\
\text { Ineligible }\end{array}$ & $\begin{array}{c}\text { Post-Promise } \\
\text { Eligible }\end{array}$ & $\begin{array}{c}\text { Post-Promise } \\
\text { Ineligible }\end{array}$ & Diff \\
& $60.5 \%$ & $51.2 \%$ & $62.4 \%$ & $36.5 \%$ & \\
Overall & & $9.3 \mathrm{ppts}$ & & $25.9 \mathrm{ppts}$ & $\mathbf{1 6 . 5}$ ppts \\
Difference & & $37.0 \%$ & $57.4 \%$ & $33.5 \%$ & \\
Students of Color & $51.6 \%$ & $14.5 \mathrm{ppts}$ & & $23.9 \mathrm{ppts}$ & $\mathbf{9 . 4}$ ppts \\
Difference & & $62.5 \%$ & $68.0 \%$ & $38.5 \%$ & \\
\hline White students & $70.6 \%$ & $8.1 \mathrm{ppts}$ & & $29.5 \mathrm{ppts}$ & $\mathbf{2 1 . 4}$ ppts \\
Difference & & $70.3 \%$ & $70.2 \%$ & $42.5 \%$ & \\
\hline Above Average GPA & $78.0 \%$ & $7.7 \mathrm{ppts}$ & & $27.7 \mathrm{ppts}$ & $\mathbf{2 0 . 0}$ ppts \\
Difference & & $32.3 \%$ & $53.7 \%$ & $29.2 \%$ & \\
\hline Below Average GPA & $43.5 \%$ & $11.2 \mathrm{ppts}$ & & 24.5 ppts & $\mathbf{1 3 . 3}$ ppts \\
Difference & & & &
\end{tabular}

For all subgroups the naïve difference-in-differences estimate (shown in the far right column) is positive, ranging from 9.4 percentage points for students of color to 21.4 percentage points for white students. Students with above-average GPAs may have benefitted slightly more than student with below-average GPAS (20.0 percentage points relative to 13.3 percentage points). However, we cannot draw any conclusions from these simple descriptive statistics.

We turn now to the descriptive trends in BA and AA attainment, first overall and then by race and prior achievement (measured by cumulative high school GPA). Figure 4 presents trends 
in AA attainment for cohorts graduating in 2004-2014, subdivided into whether the students were (or would have been) eligible for the Promise or not.

Figure 5: \% of El Dorado Students Earning an AA within 3 Years of High School Graduation

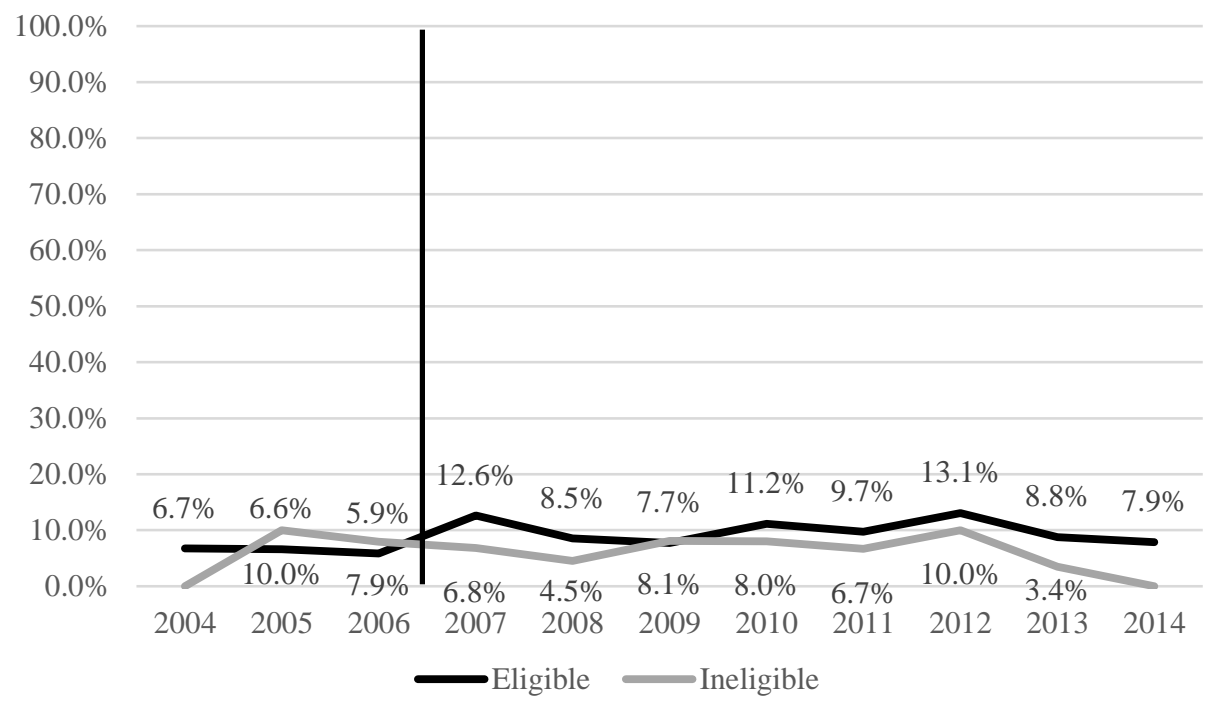

As shown in Figure 5, only a small share of any students graduating from El Dorado high school earn an AA within 3 years of graduation. The share of Promise eligible and ineligible students earning an AA hovered around 10\% for all years examined. Due the small share of students earning an AA overall and for the sake of brevity, we do not present trends over time in AA attainment disaggregated by student race and GPA in addition to Promise eligibility. Table 4 summarizes the share of students earning an AA overall and by race and GPA in the pre- and post- Promise periods. 
Table 4: \% of El Dorado HS Graduates Earning an AA within 3 Years of Graduation

\begin{tabular}{cccccc}
\hline & $\begin{array}{c}\text { Pre-Promise } \\
\text { Eligible }\end{array}$ & $\begin{array}{c}\text { Pre-Promise } \\
\text { Ineligible }\end{array}$ & $\begin{array}{c}\text { Post-Promise } \\
\text { Eligible }\end{array}$ & $\begin{array}{c}\text { Post-Promise } \\
\text { Ineligible }\end{array}$ & Diff \\
& $6.4 \%$ & $6.2 \%$ & $10.0 \%$ & $6.3 \%$ & \\
Overall & & $0.2 \mathrm{ppts}$ & & $3.7 \mathrm{ppts}$ & $\mathbf{3 . 5}$ ppts \\
Difference & & $3.7 \%$ & $8.2 \%$ & $4.1 \%$ & \\
\hline $\begin{array}{c}\text { Students of Color } \\
\text { Difference }\end{array}$ & $5.6 \%$ & $1.9 \mathrm{ppts}$ & $4.0 \mathrm{ppts}$ & & $\mathbf{2 . 2}$ ppts \\
\hline White students & $7.4 \%$ & $8.3 \%$ & $12.0 \%$ & $8.9 \%$ & \\
Difference & & $-1.0 \mathrm{ppts}$ & & $3.1 \mathrm{ppts}$ & $\mathbf{4 . 1}$ ppts \\
\hline Above Average GPA & $9.4 \%$ & $3.1 \%$ & $11.7 \%$ & $9.1 \%$ & \\
Difference & & $6.3 \mathrm{ppts}$ & & $2.6 \mathrm{ppts}$ & $\mathbf{- 3 . 7}$ ppts \\
\hline $\begin{array}{c}\text { Below Average GPA } \\
\text { Difference }\end{array}$ & $3.5 \%$ & $9.2 \%$ & $8.0 \%$ & $4.0 \%$ & \\
& & $-5.7 \mathrm{ppts}$ & & $4.0 \mathrm{ppts}$ & $\mathbf{9 . 7}$ ppts \\
\hline
\end{tabular}

Table 4 indicates that overall the Promise was associated with a 3 percentage point faster rate of growth in AA attainment among Promise eligible students than among ineligible students. However, there was variation by student characteristics, with the simple difference-in-differences estimate being greater for white students than for students of color, and for students with belowaverage GPAs than for students with above-average GPAs. We also see that, among students with above-average GPAs, the rate of increase in AA attainment was 3.7 percentage points greater for ineligible students than eligible students, which could indicate that the Promise induced above-average eligible students out of AA programs and into BA programs. We turn to this outcome next by looking descriptively at patterns in BA attainment overall and by student race and prior achievement. Figure 6 presents the share of students earning a BA within 6 years of high school graduation by Promise eligibility. 
Figure 6: \% of El Dorado Students Earning a BA within 6 Years of High School Graduation

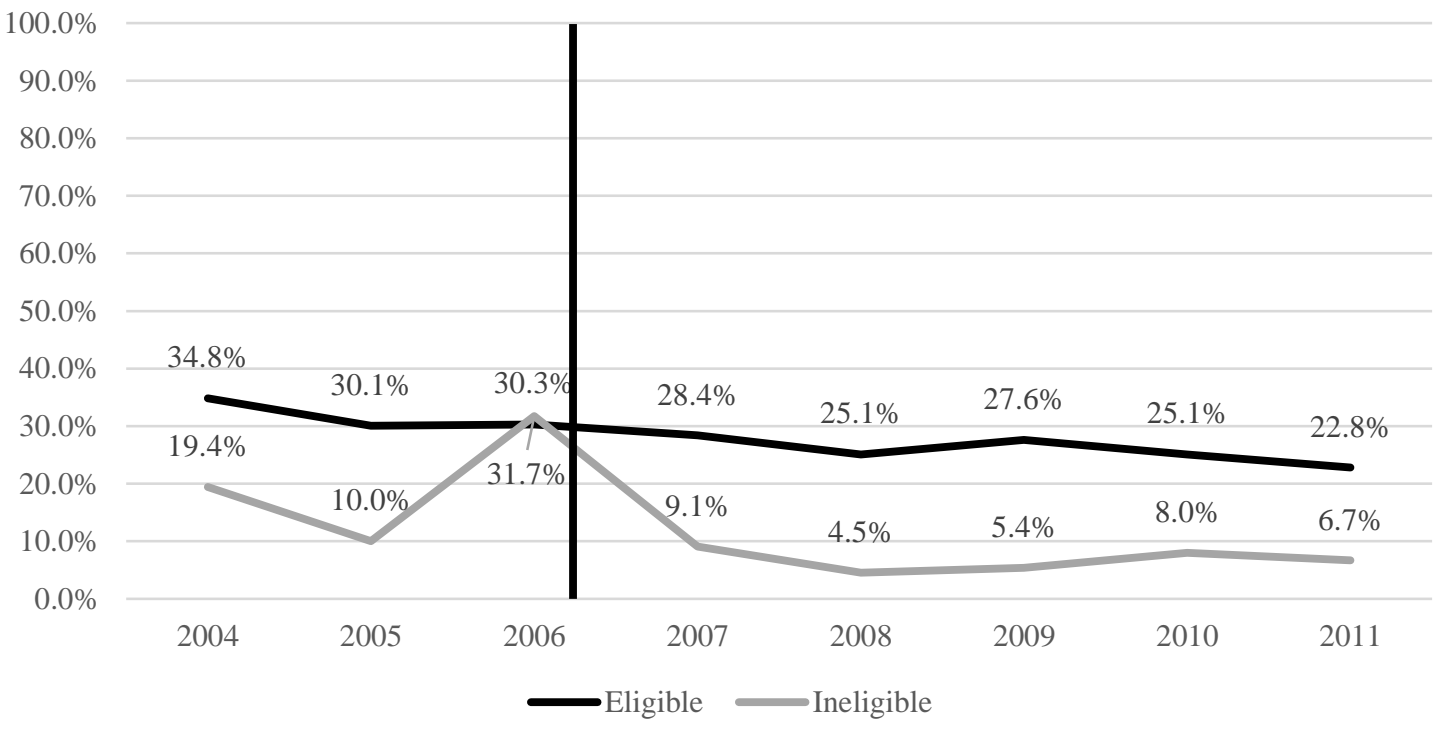

As shown in Figure 6, overall BA attainment rates were relatively flat for Promiseeligible students, hovering between $20-30 \%$ during this time. For ineligible students, rates of attainment were more volatile, but in the post-Promise period generally less than $10 \%$ of Promise ineligible students earned a BA within 6 years of graduating high school. We next disaggregate this by race, presented in Figure 7.

Figure 7: \% of El Dorado Students Earning a BA within 6 Years, by Race

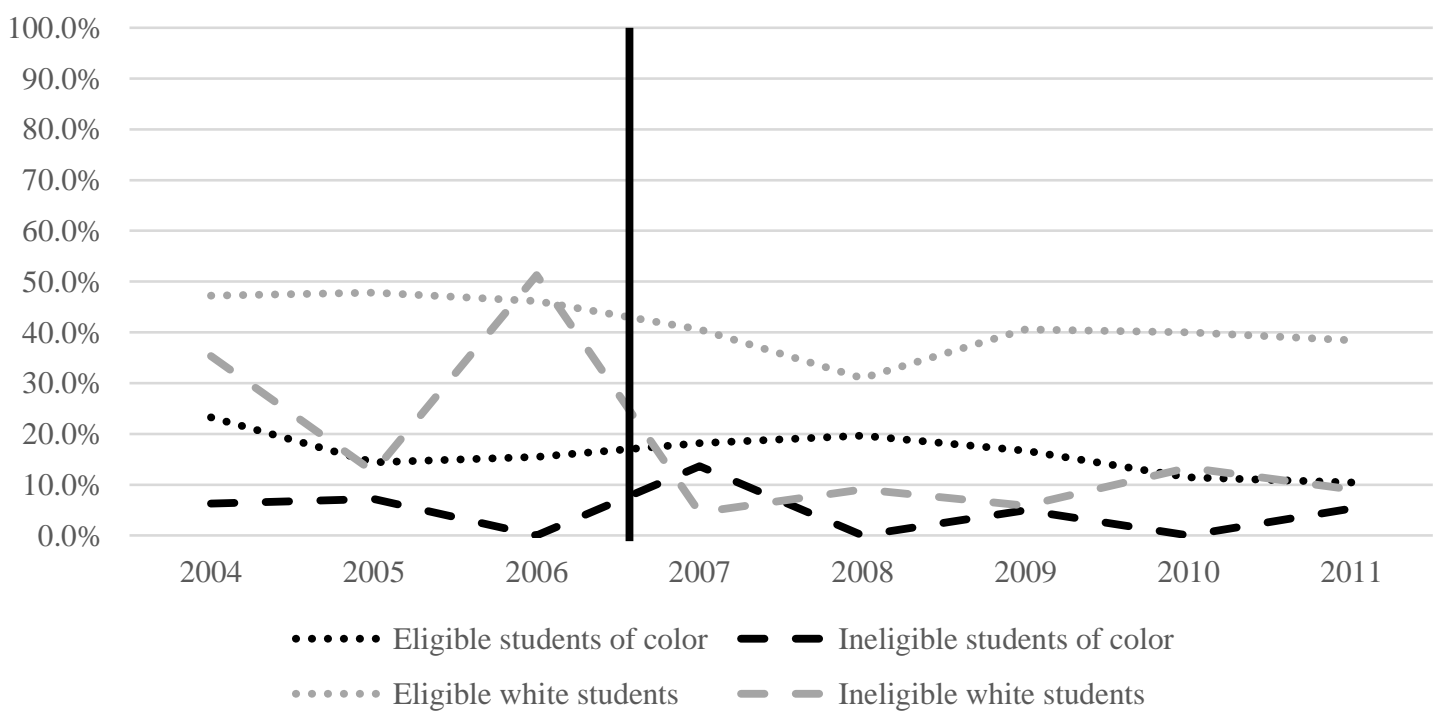


Figure 7 demonstrates that the BA attainment rates were particularly volatile for wouldbe ineligible white students in the pre-Promise period, while attainment rates for eligible students of color and white students were more stable over time. Attainment rates tended to be higher for eligible students than ineligible students for all cohorts. Figure 8 illustrates these trends based on students' cumulative high school GPA.

Figure 8: \% of El Dorado Students Earning a BA within 6 Years, by GPA

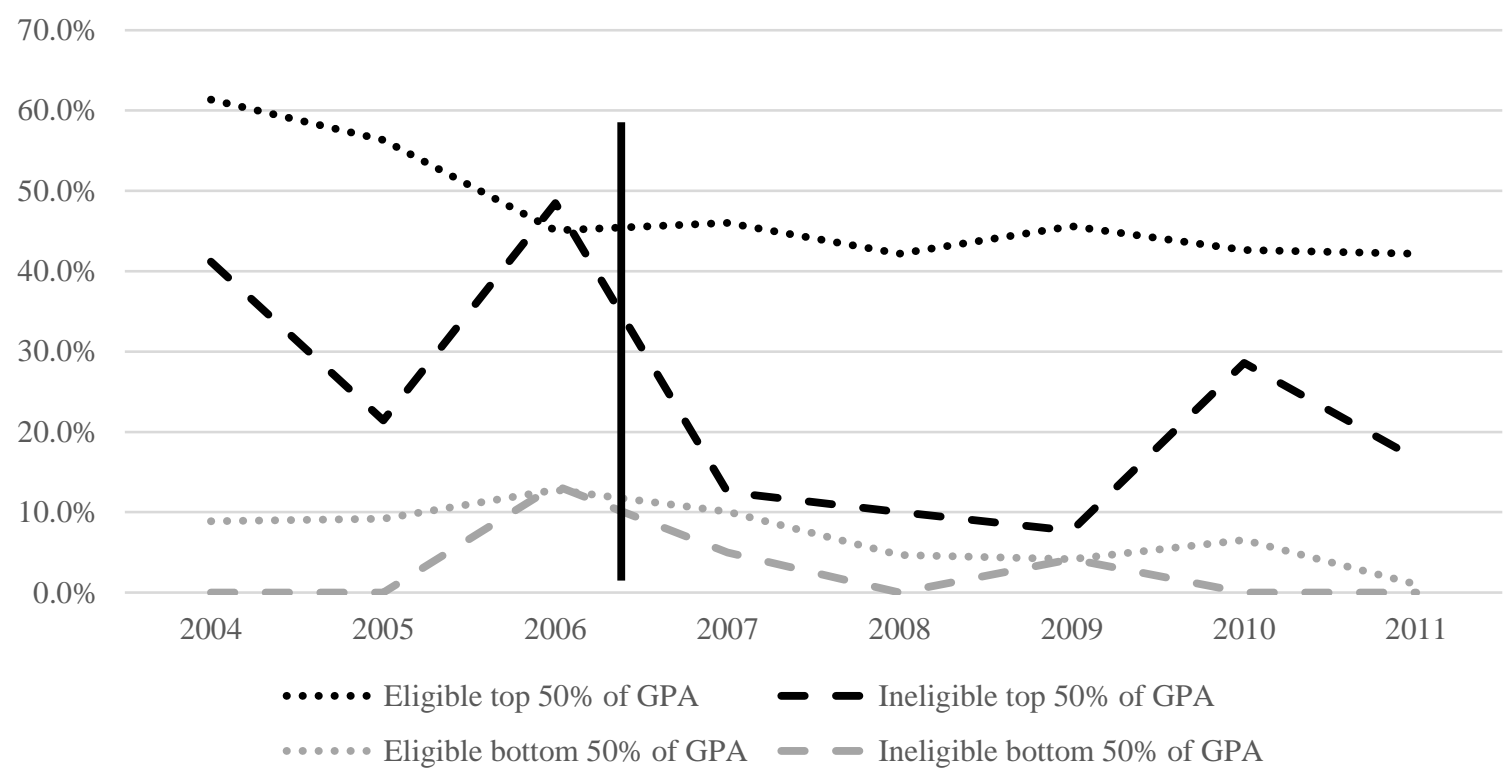

It is clear from Figure 8 that students with higher GPAs earned a BA within 6 years of graduating high school at a higher rate than students with lower GPAs. However, there is still evidence of volatility in the trends, particularly for ineligible students. Table 5 summarizes the pre- and post- Promise BA attainment rates overall, by race, and by GPA. 
Table 5: \% of El Dorado HS Graduates Earning a BA within 6 Years of Graduation

\begin{tabular}{cccccc}
\hline & $\begin{array}{c}\text { Pre-Promise } \\
\text { Eligible }\end{array}$ & $\begin{array}{c}\text { Pre-Promise } \\
\text { Ineligible }\end{array}$ & $\begin{array}{c}\text { Post-Promise } \\
\text { Eligible }\end{array}$ & $\begin{array}{c}\text { Post-Promise } \\
\text { Ineligible }\end{array}$ & Diff \\
& $31.7 \%$ & $23.3 \%$ & $25.8 \%$ & $7.0 \%$ & \\
Overall & & $8.4 \mathrm{ppts}$ & & $18.9 \mathrm{ppts}$ & $\mathbf{1 0 . 4}$ ppts \\
Difference & & $6.1 \%$ & $15.3 \%$ & $6.1 \%$ & \\
\hline Students of Color & $17.4 \%$ & $11.3 \mathrm{ppts}$ & & $9.2 \mathrm{ppts}$ & $\mathbf{- 2 . 2}$ ppts \\
Difference & & $38.9 \%$ & $38.0 \%$ & $7.9 \%$ & \\
\hline White students & $47.1 \%$ & $8.2 \mathrm{ppts}$ & & $30.1 \mathrm{ppts}$ & $\mathbf{2 2 . 0}$ ppts \\
Difference & & $40.6 \%$ & $43.7 \%$ & $13.6 \%$ & \\
\hline Above Average GPA & $53.8 \%$ & $13.2 \mathrm{ppts}$ & & $30.1 \mathrm{ppts}$ & $\mathbf{1 6 . 9}$ ppts \\
Difference & & $6.2 \%$ & $5.5 \%$ & $2.2 \%$ & \\
\hline Below Average GPA & $10.2 \%$ & $4.0 \mathrm{ppts}$ & & 3.3 ppts & $\mathbf{- 0 . 7}$ ppts \\
Difference & & & &
\end{tabular}

Although Table 5 shows that overall the rate of BA completion among Promise eligible students had a more positive rate of change than the rate of change among ineligible students, there was significant variation by student characteristics. Eligible students with above average GPAs seem to have had the greatest gains in BA attainment relative to ineligible students with above-average GPA. However, it is also clear that overall and for all groups rates of BA attainment declined over time. This is a trend worth exploring in greater detail. In the next section we detail our formal analytic strategy for examining the extent to which the El Dorado Promise impacted student postsecondary outcomes.

\section{Analytic Strategy}

To examine the impact of the El Dorado Promise on student higher education outcomes, we conducted a straightforward difference-in-differences analysis. We exploited the low eligibility thresholds for students to receive any funding from the El Dorado Promise-namely, that students must be enrolled in the district for at least $9^{\text {th }}-12^{\text {th }}$ grade in order to receive a Promise scholarship. Our basic model is given by:

$Y_{i}=\beta_{0}+\beta_{1}$ promiseeligible $_{i}+\beta_{2}$ postpromise + Seligible $*$ post $+\boldsymbol{\gamma} \boldsymbol{X}_{\boldsymbol{i}}+\tau$ cohort $_{i}+\varepsilon_{i}$, 
where $Y_{i}$ represents, in turn, each of our outcome variables: entering any postsecondary institution within 6 months, earning an AA within 3 years, and earning a BA within 6 years. promiseeligible $_{i}$ captures whether student $i$ was eligible to receive a Promise scholarship, postpromise indicates whether the Promise was in effect, $\mathbf{X}_{\mathbf{i}}$ is a vector of student level demographic characteristics (high school GPA, gender, and race), and $\tau$ captures time trends specific to each graduating cohort. Our coefficient of interest is $\delta$, which captures the impact of the Promise on student outcomes. We use a Probit model for all our analyses. For our subgroup analyses, we interact the main difference-in-differences parameter $(\delta)$ with an indicator for, first, student race and, second, above- or below- average GPA. We calculate robust standard errors for all analyses.

A key assumption of a difference-in-differences analysis is that there are parallel pretrends between our two groups. As demonstrated in the figures in the previous section, the trends in enrollment, AA completion, and BA completion were volatile in the pre-Promise period, particularly for would-be Promise ineligible students. This is most likely due the low number of students who entered the district after their $9^{\text {th }}$ grade year (and were therefore Promise ineligible); however, the trends suggest that our results should be interpreted with caution as the key identifying assumption of our analysis may not be fully met. However, this analytic strategy is the standard in the limited research examining the impact of Promise programs on postsecondary outcomes, particularly for universal programs like the El Dorado Promise that do not have GPA or other criteria that could be used in a regression discontinuity design. Thus, while the cautious reader may be justified in interpreting our results as purely descriptive, we believe this is the best strategy for attempting to estimate the impacts of the Promise on postsecondary outcomes. We present the results of our analysis in the next section. 


\section{Results}

In our main model, we control for a student's high school cumulative GPA, as this captures both observed and unobserved student characteristics that plausibly predict that student's likelihood of enrolling in and graduating from a postsecondary institution. However, it could be that the Promise had a direct impact on students' GPAs. Past work (Ash, 2015) has demonstrated that the Promise led to an increase in scores on state standardized assessments. If students were indeed learning more as a result of the Promise, then we might expect GPAs to increase as a result of the Promise as well. However, it could also be that because teachers knew more students could go to college, they raised their expectations for student work to make sure they were college-ready by the time they graduated high school. Conversely, it could be that since teachers knew students could pay for college, they were more willing to give higher grades to help students get into college, leading to grade inflation. Empirically, we see that on average GPAs increased over time: the average cumulative GPA for a student graduating in 2004 was 2.74, while the average cumulative GPA for a student graduating in 2016 was 2.78. Figure 9 plots these trends.

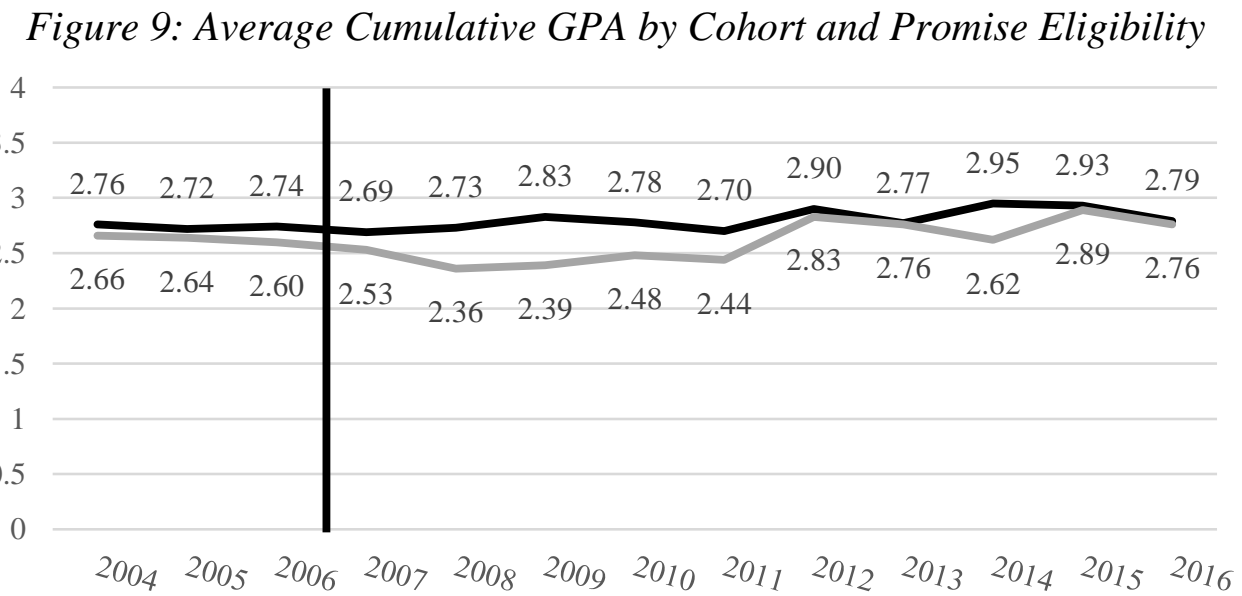

Cohort

$$
\text { Eligible cumulative GPA Ineligible cumulative GPA }
$$


Figure 9 shows that while the average cumulative GPA of El Dorado graduates tended to increase over time, it is not clear that there was rapid grade inflation (or deflation) following the announcement of the Promise. This might indicate that we can include cumulative GPA in our model and find an unbiased estimate of the impact of the Promise on college enrollment, AA completion, and BA completion. However, it does appear that average GPAs for Promiseineligible students decreased following the announcement of the Promise, and did not fully rebound until the 2012 cohort. Further, our results are sensitive to the inclusion of high school GPA in the model. Table 6 presents a summary of this when postsecondary enrollment is taken to be our outcome.

Table 6: Comparison of Estimated Impact of the Promise on Postsecondary Enrollment Descriptive DD Marginal Effect, Probit DD w/out GPA

\begin{tabular}{lccc}
\hline Overall Impact & $16.5 \mathrm{ppts}$ & $0.163 * * *$ & $0.114 * *$ \\
$($ Standard Error $)$ & & $(0.053)$ & $(0.052)$ \\
\hline \multicolumn{4}{c}{$* * * p<0.01, * * p<0.05, * p<0.1$}
\end{tabular}

(3) Marginal Effect, Probit DD w/ GPA
While the coefficients all point in the same direction, the magnitudes and level of statistical significance vary depending on whether or not high school GPA is included as a control variable. The results from the Probit when GPA is not included are most similar to the descriptive difference-in-differences. We believe that high school GPA is an important control variable that captures both student academic ability and non-cognitive skills that may be related to completing college applications in time, attending class, or visiting professors' office hours that are related to college enrollment and outcomes. Thus, in the models presented below, we control for cumulative high school GPA. However, because the magnitude of our results are sensitive to its inclusion and because GPA may have been impacted by the Promise, we also present the results of our analyses without controlling for GPA in Appendix A. 
We turn now the results of our analysis of the impact of the Promise on postsecondary enrollment. Table 7 presents the results from the difference-in-difference Probit overall and by subgroups.

Table 7: Impacts of the El Dorado Promise on Postsecondary Enrollment within 6 months of Graduation

\section{Post Promise*Eligible}

Post*Elig*Student of Color

Post*Elig*White
Post*Elig*Top 50\% GPA
Post*Elig*Bottom 50\% GPA

Post*Elig*White
Post*Elig*Top 50\% GPA
Post*Elig*Bottom 50\% GPA

Post*Elig*White
Post*Elig*Top 50\% GPA
Post*Elig*Bottom 50\% GPA

\section{$0.114 * *$}

(0.052)

Promise Eligible

Post Promise

High School GPA

Top 50\% GPA

Female

Student of Color

Observations

\begin{tabular}{rrr} 
& $\mathbf{0 . 1 3 4} * *$ & \\
& $\mathbf{( 0 . 0 5 4 )}$ & $\mathbf{0 . 0 8 7}$ \\
& $(\mathbf{0 . 0 5 5})$ & \\
& & $\mathbf{0 . 1 1 3} * *$ \\
& & $(\mathbf{0 . 0 5 5})$ \\
& & $\mathbf{0 . 2 1 5 * * *}$ \\
$0.075 *$ & & $(\mathbf{0 . 0 5 6})$ \\
$(0.044)$ & $0.077 *$ & $0.092 * *$ \\
0.021 & $(0.044)$ & $(0.044)$ \\
$(0.060)$ & 0.020 & -0.027 \\
$0.170 * * *$ & $(0.061)$ & $(0.062)$ \\
$(0.011)$ & $0.171 * * *$ & \\
& $(0.011)$ & $0.232 * * *$ \\
$0.046 * * *$ & & $(0.029)$ \\
$(0.016)$ & & $0.077 * * *$ \\
-0.007 & $0.046 * * *$ & $(0.016)$ \\
$(0.018)$ & $(0.016)$ & $-0.068 * * *$ \\
& -0.040 & $(0.017)$ \\
3,289 & $(0.029)$ & 3,423 \\
\hline & 3,289 &
\end{tabular}

Note: Marginal coefficients from Probit model presented.

Column 1 presents the overall impact of the Promise. Overall, the Promise led to an 11.4 percentage point increase in postsecondary enrollment among eligible students relative to ineligible students, an effect that is both statistically significant and practically large. The estimated coefficients on the covariates also point in the expected directions: Promise eligible 
students (e.g. less mobile students) are 7.5 percentage points more likely to enroll at a postsecondary institution than more mobile students. Similarly, as high school GPA increases, so too does a student's likelihood of enrolling in a postsecondary institution. Female students are almost 5 percentage points more likely to enroll in a postsecondary institution than male students.

Column 2 presents the impacts of the Promise separately for students of color and white students. The Promise led to an estimated 13.4 percentage point increase in postsecondary enrollment for students of color, but had no statistically significant impact on postsecondary enrollment for white students. In separate specifications, we tested whether each of these effects was significantly different from the overall effect. We found that the effect for students of color was significantly greater than the overall effect, while the effect for white students was significantly lower than the overall effect. It appears that, controlling for GPA, the overall impact of the Promise on enrollment was driven by students of color. Again, the estimated coefficients on the covariates in the model point in the expected direction.

Column 3 presents the impacts of the Promise separately for students whose GPA was above average for their cohort and students whose GPA was below average for their cohort. While students with an above-average GPA were 23.2 percentage points more likely to enroll in postsecondary than students with a below-average GPA, all else equal, the Promise seems to have induced students with above and below average GPAs into college. Specifically, we estimate that Promise-eligible students with below-average GPAs were 21.5 percentage points more likely to attend college than Promise-ineligible students with below-average GPAs. Students with above-average GPAs were 11.3 percentage points more likely to enroll at a postsecondary institution. Post hoc tests indicate that the impact of the Promise on students based 
on their prior GPA is significantly different. We turn next to the estimated impact of the Promise on AA completion within 3 years of high school graduation, shown in Table 8.

Table 8: Impacts of the El Dorado Promise on AA Completion within 3 Years of Graduation

Post Promise*Eligible

Post*Elig*Student of Color

Post*Elig*White

Post*Elig*Top 50\% GPA

Post*Elig*Bottom 50\% GPA

Promise Eligible

Post Promise

High School GPA

Top 50\% GPA

Female

Student of Color
0.040

(0.037)
(0.039)

0.037

(0.038)
0.032

(0.039)

0.050

(0.036)

$-0.000$

(0.030)

$-0.021$

(0.040)

$(0.041)$

$0.016 * *$

(0.008)

(0.030)

$-0.033$

(0.041)

$0.016^{* * *}$

(0.008)

$0.044 * *$

$(0.020)$

0.003

(0.010)

$-0.026^{* *}$

(0.012)

$-0.027 * *$

$(0.011)$

$-0.031$

(0.021)

(0.012)

(0.012)

Observations

2,740

$* * * p<0.01, * * p<0.05, * p<0.1$

Standard errors in parentheses

2,740

Note: Marginal coefficients from Probit model presented

There was no impact of the Promise on AA completion within 3 years of high school graduation, either overall or for certain subgroups of students. The overall impact is nominally estimated to be a 4 percentage point increase in AA completion within 3 years of high school graduation, but the estimate is imprecise. Similarly, the estimates for students of color, white students, students with above-average GPAs and students with below-average GPAs are nominally positive but noisy, and not even approaching statistical significance at any 
conventional level. This perhaps unsurprising, since the Promise amount is pegged to the tuition and fees for a public, 4-year institution, so the structure of the Promise does not mechanically imply that students would be induced to enroll at a 2 year institution or earn an AA. We turn now to the estimated impacts of the Promise on BA completion within 6 years of high school graduation, presented in Table 9 .

Table 9: Impacts of the El Dorado Promise on BA Completion within 6 Years of High School

Post Promise*Eligible

Post*Elig*Student of Color

Post*Elig*White

Post*Elig*Top 50\% GPA

Post*Elig*Bottom 50\% GPA

Promise Eligible

Post Promise

High School GPA

Top 50\% GPA

Female

Student of Color
0.107*

(0.060)
0.125*

(0.066)

0.091

(0.061)
$0.127 * *$

(0.059)

0.104

(0.066)

$0.087 * *$

(0.036)

(0.038)

$-0.204 * * *$

(0.064)

$0.265 * * *$

(0.011)
$-0.238 * * *$

(0.063)
(0.063)

$0.266 * * *$

(0.011)

$-0.019$

(0.017)

$-0.044 * *$

(0.018)
$-0.019$

(0.017)

$-0.063 * *$

(0.028)
$0.302 * * *$

(0.026)

0.018

(0.018)

$-0.110 * * *$

(0.017)

\begin{tabular}{ccc} 
Observations & 1,909 & 1,909 \\
\hline Standard errors in parentheses & $* * * p<0.01, * * p<0.05, * p<0.1$ & 1,978 \\
Note $:$ Marginal coefficients from Probit model presented
\end{tabular}

Note: Marginal coefficients from Probit model presented

Column 1 presents the overall impact of the Promise on BA attainment. On average, the

Promise was associated with a 10.7 percentage point increase in BA attainment within 6 years of high school graduation, but the effect is only marginally significant. Column 2 examines the 
impact of the Promise by student race. The Promise led to a 12.5 percentage point increase in BA attainment among eligible students of color relative to ineligible students, but did not have a statistically significant impact on BA attainment for white students. The impact on students of color is only marginally significant, at the $90 \%$ confidence level. Neither the effect of the Promise on students of color nor the effect of the Promise on white students can be statistically distinguished from the overall effect at conventional levels. Column 3 presents the impact of the Promise for students with above- and below- average GPAs. Students with above average GPAs appear to have benefitted most from the Promise, with an increase in BA attainment of 12.7 percentage points relative to ineligible students with above-average GPAs. This effect is marginally significant. However, there is no statistically significant impact of the Promise on students with below-average GPAs in terms of BA attainment within 6 years of high school graduation. The impact of the Promise on students with above-average GPAs is not statistically different from the overall effect of the Promise, but the impact of the Promise on students with below-average GPAs is marginally significantly less than the overall impact of the Promise.

\section{Robustness Checks}

In our main specification, we use the largest sample available to estimate effects for each of our outcomes of interest - postsecondary enrollment, AA attainment, and BA attainment. Specifically, when looking at enrollment effects we use data from 13 cohorts of students (2006 through 2016), when looking at AA attainment we use data from 11 cohorts of students (2006 through 2014) and for BA attainment we use data from 8 cohorts (2006 through 2011). In order to test the robustness of these findings, we estimate the impact of all three outcomes using a consistent sample — students graduating from the El Dorado School District between 2006 and 2011. 
Using this restricted sample, we find that the overall enrollment effect of the El Dorado Promise was 10.4 percentage points, similar to the 11.4 percentage points estimate found when using our full sample. This result is statistically significant at the $95 \%$ confidence level. This effect is again concentrated among students of color, who have an estimated enrollment effect of 12.1 percentage points (significant at the $90 \%$ confidence level) using the restricted sample. There is no statistically significant impact of the Promise on enrollment for white students using the restricted sample. However, we do see that in the restricted sample the effect of the Promise on enrollment is concentrated on students with above-average GPAs. Students with aboveaverage GPAs were an estimated 17.8 percentage points more likely to enroll in college, an effect that is significant at the $99 \%$ confidence level, but there is no statistically significant impact of the Promise on enrollment for students with below-average GPAs. This indicates that the positive impact of the Promise on students with below-average GPAs was concentrated on students who graduated between 2012 and 2016. Students who graduated in 2012, five years after the introduction of the Promise, would have been hearing about the Promise and college from $8^{\text {th }}$ through $12^{\text {th }}$ grade, so this result could reflect the importance of an increased collegegoing culture at all grades for encouraging marginal students to attend college.

When we look the impact of the Promise on AA attainment on the restricted sample of 2006-2011 graduates, we again find nominally positive but statistically insignificant impacts of the Promise on average and for all subgroups, which is consistent with our findings when using 2006-2014 graduates. Overall, it appears that our results are not substantially a function of our sample. 


\section{Discussion and Conclusion}

We find evidence that the El Dorado Promise increased postsecondary enrollment on average and particularly for students of color and students with below-average GPAs. These effects $(11.4,13.4$, and 11.3 percentage points, respectively) were statistically significant and practically large. We found no evidence that the Promise impacted AA attainment within 3 years of students' graduation from high school, either on average or for certain subgroups. We did find evidence that the Promise led to increases in BA attainment. Specifically, we estimate a 10.7 percentage point increase in BA attainment within 6 years on average, a 12.5 percentage point increase in BA attainment for students of color, and a 12.7 percentage point increase in BA attainment for student with an above-average GPA. These results indicate that the Promise package - increased emphasis on college readiness throughout K-12 and financial support throughout college — can improve students' postsecondary outcomes. These results are generally robust to decisions about sample inclusion.

While we find statistically significant and practically large estimates of the impact of the Promise on postsecondary outcomes, our results should be interpreted with caution. First, we saw descriptively that overall postsecondary enrollment and completion rates declined for students graduating between 2007 and 2016. The Promise seems to have acted as a buffer for eligible students, maintaining enrollment and completion rates or leading to slight increases, but it is clear that other factors besides the Promise were impacting both eligible and ineligible EDSD students during this time. Future work should examine these broader trends to better understand what was happening in El Dorado at the time. The national and statewide trends in enrollment did not mirror those of El Dorado during this time. These trends are shown in Appendix B. 
Next, we have limited evidence that the identifying assumption of our difference-indifferences analysis was met. Our comparison group is students who were (or would have been) ineligible for the Promise, meaning they transferred into the district after $9^{\text {th }}$ grade. This is a small group of students, and rates of enrollment and completion are volatile in the pre-Promise period, so it is difficult to determine if the eligible and ineligible students had common pretrends, which is necessary to attach a causal interpretation to the results of a difference-indifferences analysis. However, at the least our results descriptively indicate that the Promise improve students' postsecondary outcomes. Given the dearth of research on the impacts of Promise programs in general, and rural Promise programs in particular, on postsecondary outcomes, we believe that these results make a valuable contribution to our understanding of the ability of Promise programs to impact students in the long-term.

\section{References}

Andrews, R., DesJardins, S., and Ranchold, V. (2010). The effects of the Kalamazoo Promise on college choice. Economics of Education Review, 29(2010), 722-737.

Bartik, T. J., Eberts, R. W., Huang, W., \& W. E. Upjohn Institute for Employment, R. (2010). The Kalamazoo Promise, and Enrollment and Achievement Trends in Kalamazoo Public Schools. W. E. Upjohn Institute For Employment Research. Retrieved from http://research.upjohn.org/cgi/viewcontent.cgi?article=1017\&context=confpapers

Bartik, T.J., Hershbein, B., and Lachowska, M. (2017). The Effects of the Kalamazoo Promise Scholarship on College Enrollment, Persistence, and Completion. W.E. Upjohn Institute for Employment Research Working Paper 15-229. Retrieved from http://research.upjohn.org/cgi/viewcontent.cgi?article=1246\&context=up_workingpapers 
Bozick, R., Gonzalez, G., and Engberg, J. (2015). Using a Merit-Based Scholarship Program to Increase Rates of College Enrollment in an Urban School District: The Case of the Pittsburgh Promise, Journal of Student Financial Aid, 45(2), 2-24.

Carruthers, C. and Fox, W. (2016). Aid for all: College coaching, financial aid, and postsecondary persistence in Tennessee. Economics of Education Review, 51(2016), 97-112.

Castleman, B. and Long, B. (2016). Looking beyond Enrollment: The Causal Effect of NeedBased Grants on College Access, Persistence, and Graduation. Journal of Labor Economics, 34(4), 1023-1073.

Daugherty, L., \& Gonzalez, G. C. (2016). The Impact of the New Haven Promise Program on College Enrollment, Choice, and Persistence. Santa Monica, CA: RAND Corporation, 2016. http://www.rand.org/pubs/working_papers/WR1147.html.

Daugherty, L., \& Gonzalez, G. C. (2016). The Impact of the New Haven Promise Program on College Enrollment, Choice, and Persistence. Santa Monica, CA: RAND Corporation, 2016. http://www.rand.org/pubs/working_papers/WR1147.html.

DesJardins, S. and McCall, B. (2010). Simulating the Effects of Financial Aid Packages on College Student Stopout, Reenrollment Spells, and Graduation Chances. The Review of Higher Education, 33(4), 513-541.

DesJardins, S. and McCall, B. (2014). The impact of the Gates Millennium Scholars Program on college and post-college related choices of high ability, low-income minority students. Economics of Education Review, 38(2014), 124-138.

Dynarski, S. and Scott-Clayton, J. (2013). Financial Aid Policy: Lessons from Research. The Future of Children, 23(1), 67-91. 
Goldrick-Rab, S., Kelchen, R., Harris, D., and Benson, J. (2016). Reducing Income Inequality in Educational Attainment: Experimental Evidence on the Impact of Financial Aid on College Completion. American Journal of Sociology, 121(6), 1762-1817.

Gonzalez, G.., Bozick, R., Daugherty, L., Scherer, E., Singh, R., Suárez, M., and Ryan, S. (2014). Transforming an Urban School System: Progress of New Haven School Change and New Haven Promise Education Reforms (2010-2013). Research Report. RAND Corporation. Retrieved from http://www.rand.org/content/dam/rand/pubs/research_reports/RR700/RR777/RAND_RR 777.pdf

Gonzalez, G.C., Bozick, R., Tharp-Taylor, S., Phillips, A. (2011). Fulfilling the Pittsburgh Promise: Early Progress of Pittsburgh's Postsecondary Scholarship Program. Research Report. RAND Corporation. Retrieved from http://www.rand.org/content/dam/rand/pubs/monographs/2011/RAND_MG1139.pdf

Hicks, N., West, L., Amos, J., and Maheshwari, S. (2014). The Effect of Pell Grant Changes on the Graduation Rate and College Finances: A Study of Rural Community Colleges in Virginia. Journal of Business and Educational Leadership, 5(1), 142-155.

Iriti, J., Bickel, W., and Kaufman, J. (2012). Realizing “The Promise:” Scholar Retention and Persistence in Post-Secondary Education. Pittsburg, PA: University of Pittsburgh's Learning Research and Development Center. Retrieved from http://pittsburghpromise.org/assets/documents/RealizingPromise_FinalReport.pdf

Kim, J. (2012). Exploring the Relationship between State Financial Aid Policy and Postsecondary Enrollment Choices: A Focus on Income and Race Differences. Research in Higher Education, 53(2), 123-151. 
LeGower, M., \& Walsh, R. (2014). Promise Scholarship Programs as Place-Making Policy: Evidence from School Enrollment and Housing Prices. Presented at APPAM 2014. Retrieved from http://www.appam.org/assets/1/7/Promise_Scholarship_Programs_2014.pdf

Linsenmeier, D., Rosen, H., and Rouse, C. (2006). Financial Aid Packages and College Enrollment Decisions: An Econometric Case Study. The Review of Economics and Statistics, 88(1), 126-145.

Miller-Adams, M. (2015). Promise Nation: Transforming Communities through Place-Based Scholarships. Kalamazoo: W.E. Upjohn Institute for Employment Research.

Population.us (2016). Population of El Dorado, AR: Historical population. Retrieved from http://population.us/ar/el-dorado/

Sohn, H., Rubenstein, R., Murchie, J., and Bifulco, R. (2016). Assessing the Effects of Place Based Scholarships on Urban Revitalization: The Case of Say Yes to Education. Educational Evaluation and Policy Analysis, 39(2), 198-222.

Swanson, E., Watson, A., Ritter, G., and Nichols, M. (forthcoming). Promises Fulfilled? A Systematic Review of the Impacts of Promise Programs. Available at http://www.uaedreform.org/downloads/2017/11/promises-fulfilled-a-systematic-reviewof-the-impacts-of-promise-programs-2.pdf

Welch, J. (2014). HOPE for community college students: The impact of merit aid on persistence, graduation, and earnings. Economics of Education Review, 43(2014), 1-20.

Zhang, L., Hu, S., and Sensenig, V. (2013). The Effect of Florida's Bright Futures Program on College Enrollment and Degree Production: An Aggregated-Level Analysis. Res High Educ, 54, 746-764. 


\section{Appendix A: Results from Alternative Specifications}

Table A1: Impact of the El Dorado Promise on Postsecondary Enrollment without Controlling for High School GPA

(1)

Overall Impacts
(2)

Impacts by Race
(3)

Impacts by GPA

\section{Post Promise*Eligible $\quad 0.163 * * *$}

(0.053)

\section{Post*Elig*Student of Color}

Post*Elig*White

Post*Elig*Top 50\% GPA

Post*Elig*Bottom 50\% GPA
Promise Eligible

Post Promise

Female

Student of Color

$$
\begin{gathered}
0.098 * * \\
(0.045) \\
-0.015 \\
(0.062) \\
0.101 * * * \\
(0.016) \\
-0.122 * * *
\end{gathered}
$$

(0.016)

\section{$0.179 * * *$}

(0.055)

$0.140 * *$

(0.057)

$0.226 * * *$

(0.053)

0.102*

(0.053)

$0.093 * *$

(0.045)

$-0.011$

$(0.062)$

$0.086 * * *$

$0.101 * * *$

(0.016)

$-0.090 * * *$

$-0.149 * * *$

(0.029)

(0.017)

Observations

3,423

3,423

Standard errors in parentheses

$* * * p<0.01, * * p<0.05, * p<0.1$

Note: Marginal coefficients from Probit model presented 
Table A2: Impact of the El Dorado Promise on AA Completion without Controlling for High School GPA

(1) (2) (3)

Overall Impacts Impacts by Race Impacts by GPA

Post Promise*Eligible $\quad 0.037$

(0.036)

Post*Elig*Student of Color

Post*Elig*White

Post*Elig*Top 50\% GPA

Post*Elig*Bottom 50\% GPA

Promise Eligible

Post Promise

Female

Student of Color

0.005
$(0.030)$
-0.017
$(0.040)$
0.008
$(0.011)$
$-0.035 * * *$
$(0.011)$

0.039

(0.038)

$\mathbf{0 . 0 3 5}$

(0.038)

0.048

(0.036)

$\mathbf{0 . 0 2 3}$

$(\mathbf{0 . 0 3 7 )}$

0.004

(0.030)

$-0.020$

(0.039)

0.005

(0.011)

$-0.029 * *$

(0.011)

Observations

2,852

Standard errors in parentheses

2,852

2,852

$* * * p<0.01, * * p<0.05, * p<0.1$

Note: Marginal coefficients from Probit model presented 
Table A3: Impact of the El Dorado Promise on BA Completion without Controlling for High School GPA

(1)

Overall Impacts Impacts by Race Impacts by GPA

\section{Post Promise*Eligible}

Post*Elig*Student of Color

Post*Elig*White

Post*Elig*Top 50\% GPA

Post*Elig*Bottom 50\% GPA

Promise Eligible

Post Promise

Female

Student of Color
$0.151 * *$

(0.063)

\begin{tabular}{rrrr} 
Promise Eligible & $0.107 * * *$ & $0.111^{* * *}$ & $0.089 * *$ \\
& $(0.040)$ & $(0.040)$ & $(0.036)$ \\
Post Promise & $-0.245^{* * *}$ & $-0.243 * * *$ & $-0.242^{* * *}$ \\
& $(0.069)$ & $(0.070)$ & $(0.063)$ \\
Female & $0.074 * * *$ & $0.074 * * *$ & $0.037 * *$ \\
& $(0.019)$ & $(0.019)$ & $(0.018)$ \\
Student of Color & $-0.232^{* * *}$ & $-0.256 * * *$ & $-0.159 * * *$ \\
& $(0.017)$ & $(0.029)$ & $(0.017)$ \\
& & 1,978 & 1,978 \\
\hline Otandard errors in parentheses & 1,978 & $* * * p<0.01, * * p<0.05, * p<0.1$
\end{tabular}

$0.173 * *$

(0.069)

$0.131 * *$

(0.064)

$0.255 * * *$

$(\mathbf{0 . 0 5 7 )}$

$-\mathbf{0 . 0 7 7}$

(0.061)

$0.089 * *$

$(0.036)$

$(0.063)$

$0.037 * *$$$
\text { (0.017) }
$$

Standard errors in parentheses 


\section{Appendix B: Trends in Postsecondary Enrollment and Completion}

Figure B1: Trends in Postsecondary Enrollment (Biannual, 2004-2014)

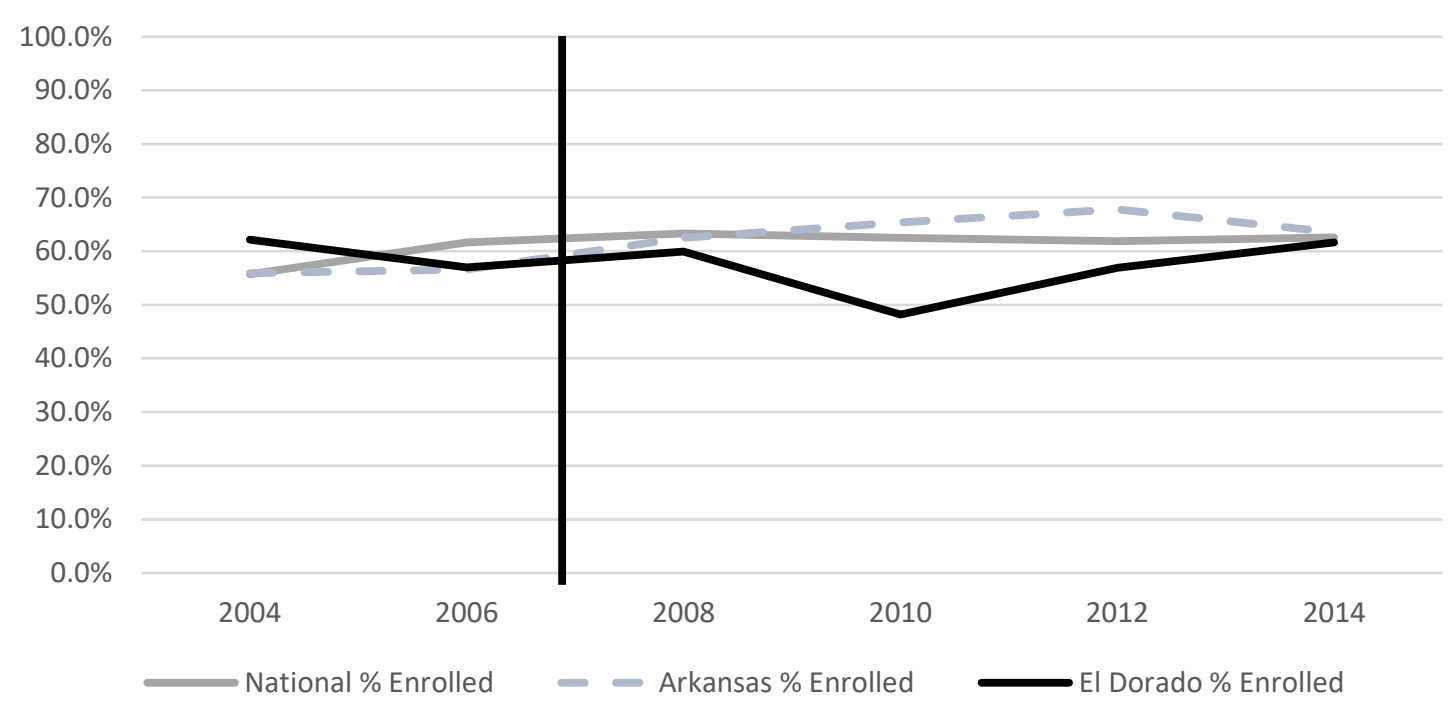

Source:

http://www.higheredinfo.org/dbrowser/index.php? submeasure $=63 \&$ year $=2014 \&$ level $=$ nation $\&$ mode $=$ da ta\&state $=0 \# /-1 /$ 